\title{
Melanoma of the Iris pT4a TNM Finding v7
}

National Cancer Institute

\section{Source}

National Cancer Institute. Melanoma of the Iris pT 4a TNM Finding v7. NCI Thesaurus.

Code C88681.

Melanoma of the iris with extrascleral extension less than or equal to $5 \mathrm{~mm}$ in diameter.

(from AJCC 7th Ed.) 